\title{
Ovarian Cellular Fibroma
}

National Cancer Institute

\section{Source}

National Cancer Institute. Ovarian Cellular Fibroma. NCI Thesaurus. Code C7291.

A benign neoplasm arising from soft tissue of the ovary. It is characterized by the presence of spindle-shaped fibroblasts and increased cellularity. 